DOI: 10.17951/lrp.2020.39.2.259-274

\author{
BeATA MydŁowsKa \\ Uczelnia Społeczno-Medyczna w Warszawie \\ ORCID - 0000-0003-3235-1289
}

\title{
GLOBALIZATION AS A CHALLENGE FOR PROFESSIONAL EDUCATION
}

\begin{abstract}
This article deals with vocational education as an element of globalization in the modern world. The aim of the article is to determine the basic issues in the field of vocational education in times of globalization. The article focuses on such issues as the specificity of vocational education in Poland and in the world, the importance of vocational education for the contemporary world, the concept and features of globalization, determinants of globalization in the modern world and vocational education as a result of globalizing the world today. A man from a citizen of a given state has become a citizen of the world. This fact brings with it both a lot of advantages and many threats, including in the sphere of vocational education, for which ubiquitous changes have brought many new challenges. This particularly applies to the adaptation of curricula to the needs of societies operating in new economic, social and cultural conditions, including taking action to reduce the disproportion between the knowledge mastered by students and the skills or the extension of specialist education. Vocational education must face the necessity of changing priorities in order to educate mobile employees of the market economy, active and capable of continuous self-education, in accordance with globalization trends.
\end{abstract}

Keywords: vocational education, globalization, competences of the future, specialized education

\section{INTRODUCTION}

The aim of the article is to analyse globalization factors affecting vocational education. Already at the end of the 1990s, there was a rather rapid change in the development of both technology and education, which was significantly influenced by technological progress unprecedented in previous periods, especially in the field of electronic communications. Its consequence is the fact that nowadays facilitated 
interpersonal communication has brought people closer on the one hand, and on the other, close contacts have been significantly limited by the development of media for internet communication.

New times have brought further challenges for pedagogy, giving birth to many dilemmas that have no clear-cut solutions. This applies in particular to vocational education, because the rapid pace of changes caused by the spread of new technologies has resulted in significant changes in the structure of demand for employees. In English-language sources (Drucker 2001, p. 81) from the beginning of the 21st century, information appears that the number of workers who have gained professional qualifications mainly through work has decreased, while the employment of knowledge workers whose professional work is preceded by a long period of study in formal school systems and whose nature of work requires supplementation of knowledge throughout life. It is said that the labour market is being replaced by the knowledge market. Growing trends related to the popularity of skilled knowledge workers on the labour market cause the development of professional groups traditionally considered to be highly qualified, which form the so-called "Knowlegde technologists", e.g. laborers, paramedics, programmers, etc. - specialists who are now becoming the dominant segment in the employment structure in developed countries, ousting the largest group of industrial workers until recently.

Therefore, an important task of vocational education is to properly prepare the student for the creative use of the achievements of civilization, both the achievements of the world of technology and values that support the implementation of the basic goal of technical education, which is the improvement of every citizen of the world so that he can participate more fully, while maintaining humanistic attitudes, in technological changes.

\section{THE CONCEPT AND FEATURES OF GLOBALIZATION}

Globalization is a process that occurs in the global economy, characterized primarily by the increase in mobility as well as flow of goods, capital, as well as so-called workforce on a global scale, the development of transport, communication and telecommunications, and the rapid transfer of critical information in the media. This economic evolution is often accompanied by transformations in the following spheres: social, cultural, political and political, which lead to confrontation, as well as rapprochement in this respect between countries, nations or people of the whole world. Thus, globalization has its economic and political, social and cultural dimension. Thus, the following question arises - how will globalization 
affect the further development of education, management and prosperity, as well as freedom and democracy on the one hand, on the other, on a global scale.

The literature on the subject often presents the reflections of political scientists who ask themselves to what extent globalization allows adequate control and control over all socio-political processes on a global scale. In addition, this is associated with a quite controversial discussion around the concept of "Global Governance" adopted from the English language, understood as "shaping the global order" or less often: "global internal policy", or as a less realistic concept of the so-called "World government". In essence, it is about the need for a broad reflection on the management of all future relations between the theoretical approach and the real dimension of the globalization process in the general economic sphere and all its consequences for the entire international system, as well as the role of states as its most important participants (Wawak 2000).

Globalization is also a progressive, important process of integrating an increasing number of countries' economies across their borders by expanding mutual investment, trade, production and cooperative links. It is presumed that this will result in the creation of a general, global economic system with a fairly large correlation - such a globalization process is shaped by long-term and comprehensive changes, taking place mainly in three areas, which include: scientific and technical progress, liberalization of international flows of goods and capital and international competition (Kaczmarek 2011, pp. 55-58).

At the same time, it is impossible to forget about the growing disparities and development asymmetries between individual countries. Globalization is also an important problem on an international scale in terms of scarcity, misery and breaking the law man, migration, numerous threats to peace and environmental protection. Therefore, there are complex, socio-political and economic processes on a global scale that already require much more thoughtful and coherent development strategies (Senghaes 1997).

The globalization process today concerns an increasing number of different activities. The characteristic features of globalization are as follows (Sporek 2015, pp. 13-42):

1. Political democratization.

2. The liberalization.

3. Participation, i.e. participation, deciding on certain things, problems.

4. Knowledge transfer, which often goes in two directions, ie towards markets as well as towards international organizations.

5. Very fast development of all modern techniques and technologies, mainly related to the development of computer techniques or telecommunications. 
The development of these fields enabled quick contact of people from various countries of the world.

6. Transformation to a completely open market economy.

7. The emergence of a new category, i.e. emerging markets.

Undoubtedly, globalization, by favouring the overall unification of markets, production systems as well as trade and capital flows, often leads to the polarization of people living in individual countries and regions. On the other hand, a rather interesting tendency that is emerging in the modern world is the intensification of regional economic cooperation, which on the one hand is an important response to the progressing globalization, on the other hand it creates the opportunity for gradual adaptation of individual countries to the requirements of global competition (Maśloch 2005, p. 24-25).

Thanks to the development of technology, local, national and international communities, in contrast to those of the past, are interdependent on a fairly large scale - therefore globalization changes the dimensions of time and space, thereby causing space flattening and significant "shrinking of time", but also the entire globe (Rosenau 2000, p. 92). In modern times it is not surprising that, for example: a businessman from Stockholm every morning gets on a plane, goes to a conference in London, and on the same day in the evening he returns home. Similarly, instead of constantly traveling around the world to discuss key issues for the development of the company, he organizes teleconference himself by talking to entrepreneurs from around the world.

Another indicator of progressing globalization is not only the focus on information exchange, but also on consumption as a basic human activity.

In accordance with the view of Zygmunt Bauman, we are entering liquid modernity, full of uncertainty and fragmentation, which is not affected even by the sphere of professional activity. Earlier, work ensured both livelihood and a specific position and status in society - it was an indicator of social and individual identity. The profession and position were the answer to the question: who are you? (Bauman after: Karczewska, 2016, p. 40). In a world dominated by globalization processes, consumption has become the basic value in human life, considered as a source of unlimited gratification and satisfaction, and improvement of social status (Bylok 2012, p. 35). According to Z. Bauman, globalization is characterized by the transition from a production era based on work ethics to a consumption era based on aesthetics of consumption - fulfilling obligations has been replaced by the need for consumer experience, succumbing to consumer cravings, experiencing newer "impressions", indulging in constant search and shaping your own image, achieving goals through consumer behaviour (Bauman 2006).

The progress of globalization is evidenced by the development of fiber optic and satellite connections. They enable very efficient communication even with 
distant ends of the globe. Mainly thanks to communication technologies such as e-mail, Internet or mobile telephony, you can maintain constant contact with both family and friends, work remotely, etc. (Czerny 2007, p. 11).

Generally, globalization means the global scale, importance and way of solving problems affecting the development of all societies and seeking solutions to current problems with the best, multifaceted cooperation of all parties.

It should be emphasized, however, that globalization is not only the domination of technology over culture, which brings new social and economic opportunities for economic development and increase in prosperity. It also causes drastic changes in experience and, consequently, changes in thinking and awareness. In the sphere of work, there is an increase in the importance of the role of human capital management, a decrease in the role of work as physical effort, multi-employment, the disappearance of some professions and the emergence of new ones (especially in the IT sector), the development of telework as an example of new forms of work organization, treatment of robots and automatons as a new, more and more popular group of manufacturers, etc.

In the light of these requirements and the situation on the labour market, related to the growing shortage of employees, the vocational education and related competences of the future have an important element on the globalization process, which Stefan M. Kwiatkowski (2018, p. 26) presents as follows:

- general professional competences (specific to formal education), common for groups of professions (design, development of project implementation procedures, extensive use of IT tools, teamwork, team creation and management of their work);

- professional competences resulting from the need to perform professional tasks (initially the domain of formal education, and later non-formal and informal education), having a sectoral (industry) character;

- specific professional competences related to:

- the possibility of transforming professional skills (along with technological changes);

- integration of professional knowledge and skills from various areas (industries) -mechanics and electronics, IT and medicine, IT and environmental protection, chemistry and medicine, biology and technical sciences, etc.

Phenomena such as continuing education, modification of teaching systems for the development of a knowledge-based society, distance learning, virtual knowledge bases (including virtual libraries), etc. also play an important role in the sphere of education. 


\section{THE SPECIFICATION OF VOCATIONAL EDUCATION IN THE CON- TEXT OF GLOBALIZATION CHANGES}

Globalization processes have required educational authorities to take action corresponding to the changes caused by the transition to a new paradigm - systemic, with which modern science appeared after the end of World War II. As early as 1970, Marian Mazur said of the scientific revolution that had occurred at that time that it was a "real explosion of interdisciplinary sciences" (Mazur 1970, p. 11). Thomas Kuhn (2001) ascribed it to the crisis in the humanities and acknowledged that it had contributed to the development of many strict theories accelerating scientific and technical progress. This progress, by influencing the development of globalization processes, forces the transformation of the vocational education system - first of all taking into account the specialties related to computerization, miniaturization, the use of satellite communications, optical fibers (e.g. for data transmission).

Natasza Lubik (2008, p. 92) is associated with globalization with the development of modern science and convinces about the legitimacy of calling the system paradigm the system-cybernetic paradigm and drawing attention to the need for introduction to education professional multidiscipline and replacing the explanatory method with research methods focused on not only researching the elements of reality as such, but also examining the relationship between them.

Barbara Krauz-Mozer and Robert Borowiec (2008, pp. 35-37), referring to earlier studies by Manuel Costellas and concluding from their own, pointed out that a new type of network-based social structure has resulted in the emergence of global communication that requires skills related to the appropriate handling of information. This includes, among others: analysing, drawing conclusions, creating new information, applying it in practice, etc. This in turn causes a new understanding of entrepreneurship - in 2007 Józef Penc (2010, p. 504) appealed for entrepreneurship intellectual, which is shaped by appropriate education and creating new knowledge that has practical application. This was particularly true of vocational education, in which students should be minded about dispositional thinking ${ }^{1}$.

In response to globalization changes in Poland, the current basic vocational schools have been transformed into first-degree industry schools. It is a new type

1 This term was taken from Foucault's social thought, which by referring to the concept of dispositional thoughts about "a qualitatively new, paradigmatic research perspective trying to reflect not only the discursive images of the world, but also the relationship between discourse and experienced reality [...] or even a discursive-non-discursive construction of reality" (Nowicka 2011, p. 96). 
of school representing a new quality of education, focused both on the needs of employers and on the labour market. The structure of education and the quality of its functioning have become factors significantly affecting local labour markets A modern vocational school should become a place where the employees creating demand for work and employees constituting its resources meet (Tarkowski et al., 2016). However, in line with global trends, not only is the increase in the popularity of vocational schools not observed, but a surplus of university graduates has been observed, which is particularly evident in unemployment statistics and in the commonly reported by entrepreneurs mismatching the structure of education with market needs, which seems to indicate a lack of education entrepreneurship. This is often associated with the ambition on the part of parents to make decisions about the general education of their children, and then to study at higher education fields that do not guarantee achieving a satisfactory position on the labour market. Therefore, Polish schools must be particularly focused on practical skills, but at the same time offer the foundation of vocational education that will allow a graduate of a second-degree trade school to take the matura exam.

Changes in industry education are planned from the 2019/2020 school year. In addition, according to the project, local governments will receive an increased educational subsidy for students of vocational education schools, for which there is a higher demand in the modern labor market, indicated in the general forecast of the demand for specialist employees in vocational education professions. This forecast will be determined by the minister of national education in a special announcement. Students of an industry grade I school who are not young workers, as well as technical school students, under a contract with their employer, will be able to complete a student internship. This participation will enable the student to learn the profession in real working conditions, as well as to get to know the workplace and to become thoroughly acquainted with specific positions. In turn, the employer will be able to meet and properly prepare a potential employee. All costs of cash benefits that each student receives during the internship will be included in the tax deductible expenses of the employer. In addition, a compulsory professional exam will be introduced (Act of 22 November 2018).

The above is in line with the trends in force in Europe, where the vocational education system, represented by both vocational and technical schools of various levels, also at higher levels, plays a significant role, which is presented in the data from the countries listed below (Kabaj 2004, pp. 14-18): 
- Germany - 69\% of students from vocational schools learn their profession mainly in the dual education system ${ }^{2}$, and $31 \%$ of them learn in the vocational school system;

- Switzerland $-87 \%$ of vocational school students participate in the dual vocational training system and $13 \%$ in the vocational school system;

- Hungary - over $37 \%$ of students continue their vocational education in the dual vocational education system, while $63 \%$ of students study the vocational education system,

- Czech Republic - 58\% of all vocational school students are educated in the dual vocational education system, and $42 \%$ continue their education in the vocational school system;

- Netherlands - 33\% of participants of the entire vocational education learn a specific profession in the dual education system, and as much as $67 \%$ of students participate in the school education system.

The European Alliance for Vocational Preparation (Eafa), which was launched in July 2013 and supports the reform of vocational training systems in EU countries (OECD 2015) by encouraging implementation, can help dual learning initiatives, bilateral and national agreements, initiatives and cooperation mechanisms. Reforms based on the design and implementation of proven, concrete solutions enabling the introduction of a system inspired by the education model used in Germany are preferred here. This support is based on consultation and the creation of 30 regional vocational training networks with the participation of Germany - Germany has signed effective bilateral agreements and currently supports Greece, Italy, Latvia, Portugal, Slovakia and Spain in the field of education reform, improvement and vocational training.

Noteworthy is also the Finnish education system known around the world, in particular above average student results. Its high efficiency is attributed to many factors, while the main goal of vocational education at the secondary level is to equip the student with professional skills. Vocational schools offer support to all

2 The model of vocational education called the dual system assumes the combination of a practice (referred to as employment on the basis of an employment contract between an employer and employee) with theoretical science. That is why the dual system is also called a two-track system because it consists in learning the profession organized by the employer as well as theoretical and general education in the school system or out-of-school forms. It is particularly widespread in Germany, where more than $2 / 3$ of young people choose the dual system as a further education path, then finding employment most often with the employer with whom they were educated. The federal level institutions are involved in the dual education system in Germany (Ministry of Education and Research Scientific), federal states, chambers of industry, commerce and crafts, employers and students who themselves are looking for employers in their chosen profession (Dziewulak 2013). 
weaker students, each school always employs a social worker, students rarely lose a lesson, e.g. due to teacher's illness - the school usually provides a replacement (Kabaj, 2004). The overall goal of theoretical and practical Finnish Vocational Training (TPZ) is to improve professional skills, provide opportunities to respond to the needs of the labour market, and lay the foundations for a lifelong learning process. TPZ consists of apprenticeship at the basic, in-depth and supplementary level - 119 curricula are implemented there, giving vocational qualifications in 53 specialties. There are also many initiatives that aim to raise the level of vocational education and improve it standards and status, such as the national competition of professional skills, as a result of which young masters of the profession are selected - representatives of over thirty industries are represented in the competition, participants of the competition must be under 23 years old and must be graduates or students of vocational education institutions. The process of teaching in the workplace is also fashionable - embedded in real situations from practice and other ideas improving the quality of vocational education.

In Poland, one of the key solutions seems to be cooperation with future employers, which benefits both parties, which is manifested in the creation of patron classes, the possibility of undergoing apprenticeships or co-financing modernization of school infrastructure by cooperating companies (Pacuk et al. 2016). It is also beginning to notice that for vocational education it is becoming important that the dominant transmission and reproductive model, anachronistic in the age of the knowledge society, be replaced as soon as possible by the generative model, whose main components are: multilateral teaching, problem teaching, teamwork students, problem teaching in teams, programmed teaching in various versions and teaching for the championship. Changes in the labour market even determine changes in education, above all the school system, both in quantitative and qualitative terms. In addition, they strongly force reforming program and structural education. Czesław Banach (2001, pp. 206-207) is right when he considers it necessary:

- multi-level and wide-profile education, as well as individualizing educational paths, in particular by enabling general as well as vocational education in the general school and non-school education system;

- broadening the educational offer primarily in terms of school networks, as well as forms and methods of vocational training according to various socio-economic and cultural needs and in all levels of education;

- increasing the number of people studying at the vocational level with simultaneous reconstruction of the whole of higher education;

- adaptation of fields of education to the general needs of the labor market with simultaneous connection of the school with adult education and using 
both conventional and unconventional methods and forms of education, including distance learning or e-leaming;

- increasing the number of teachers of vocational education, especially professors, or social higher education, as well as financial support for students to guarantee their education conditions;

- creating a reliable system for assessing the overall quality of studies and accreditation;

- creating a network of institutions mainly of a psychological and pedagogical nature, in particular helping those interested to make appropriate choices in education, as well as professional work, and making retraining decisions. Vocational school should continue to perform caring and educational functions, based on it properly shape attitudes of openness to new knowledge and all values related to it, in such a way that the information obtained in all types of education serves to develop thinking, interests, operationalization of knowledge or learning using appropriate dialogue, modern technologies and a strong sense of agency.

\section{THE IMPORTANCE OF VOCATIONAL EDUCATION FOR CONTEMPORARY CHANGES}

For the modern world, vocational schools are primarily a back-up for the labour market - on the one hand, they give students a high probability of employment, and on the other, they provide qualified employees. Vocational training makes it possible to meet the challenges that are created by socio-economic transformations and rapid technological development. The conditions of our reality even enforce the need for constant, expanding knowledge and skills. Vocational education is beginning to be perceived as a long-lasting and knowledge-rich process enabling acquiring new competences and qualifications necessary in professional work and in everyday life. Education shows how to use the latest achievements, how to define the danger arising from changes and to take actions that significantly minimize its negative effects. In addition, vocational education is an integral part of the development of every society and development of all people, inspires and stimulates action (Delors 1998, p. 7).

Modern man in particular enriches, deepens and systematizes already acquired knowledge, thanks to which he also verifies and changes his activities, and thus, constantly tries to adapt to the ever-changing world (Social Diagnosis 2011, p. 24). In the face of ongoing changes, it seems inevitable and necessary to change the traditional vocational training system to a more modern model. It should release 
cognitive desire, the need for action and self-fulfilment in a person, and meet the expectations of those who want to improve their qualifications. A student is not only a young man who is looking for his place, but often it is an adult, having some luggage of professional experience, specific expectations and aspirations, expecting something more than just gaining and enriching knowledge itself, expects hints in the area of problem solving in the light of the conditions of the immediate environment and environmental requirements. The goal of every vocational school, as well as other institutions that deal with adult education, is increasingly becoming equal access to education for all interested parties, as well as creating a flexible educational offer that would be consistent with the overall strategy of higher education, allowing to combine learning with work performed.

Another aspect of the role of vocational education in solving the problems of the modern world is dealing with unemployment caused by labour-saving economic growth - extending the period of education is now becoming one of the forms of alleviating this problem. Similarly, in the case of another phenomenon - shortening the lives of companies, resulting from the fact that the rapid pace of change intensifies competition and causes that a negligible number of companies now operates longer than the period of their employees' professional activity. Mergers and acquisitions, a change in the company profile and often even a fall mean for many employees the need to change jobs and the associated change or supplementation of qualifications.

It is also worth paying attention to the problem of the effects of making the labour market more flexible - the increase in the number of employees employed in the system of periodic and commission contracts is associated with shifting the costs of changing or raising qualifications, which companies usually incurred to employees. This mobilizes them to a more thorough analysis of the advisability of choices not only of the fields of study, but also the extent of involvement in the life of the company in which employment is undertaken and care for its condition on the economic market.

Vocational education, becoming a guarantee of having knowledge and specific practical skills, is a guarantee of introducing causative, pragmatic and creative people to the labour market. It gives a chance to make full use of the rights of freedom in becoming a seeker, a man of the future in a general, positive understanding of this phenomenon, even a constructor of life who bears responsibility mainly for his own and others' fate, and in accordance with the contemporary cultural ideas of building a community of so-called "Hearts and minds" of humanity (Hejnicka-Bezwińska 2008).

Vocational education, considered in the economic and social aspect, has a strong impact on the development of young members of society - helping students 
anticipate and cope with changes in the labour market, showing opportunities arising from raising and improving qualifications, retraining, etc., shows how to get a satisfying job or higher earnings, secure personal development, talents and skills, how to counteract marginalization and social exclusion, eliminate social inequalities, shape the right attitude towards the world of values and other people. Students also have a chance to understand that today's employers from a potential employee nowadays do not expect one-dimensional professional qualifications, but above all their readiness to develop their personality predispositions, communication and interpersonal skills, availability and readiness for change. The combination of theory and practical learning will ensure a high level, e.g. through specialized workshops and apprenticeships in workplaces, along with obtaining a diploma enables graduates to quickly enter the labour market and achieve financial independence.

Vocational education protects against life helplessness, getting lost in new working conditions and long-term unemployment, contributes to the increase of salary of future employees, gives a new perspective on work as a value. Therefore, it becomes a kind of good deciding about a given social position of the individual. As D. Kukla rightly points out (2006, p. 66), due to appropriate vocational education, modern youth gain the awareness that most people of the 21 st century will have to learn new professions and skills in order to work, they will even have to move in search of work from city to city, as well as to remote regions of the country or the world, and the overriding aspect of a professional career is the continuity of individual development at every stage of life, whose main goal is to achieve success mainly in professional work. It will be important to take into account the currently emerging trends changing priorities in the field of changing education directions, as noted by Stefan M. Kwiatkowski, cited above (2018, p. 25), saying that "an increase in the quality of life already results in the emergence of professions operating in the sphere of: dietetics, cosmetology, aesthetic medicine, various types of consultancy, organization of free time".

A special role is played by the vocational training system, which is co-shaped by entrepreneurs - if practical vocational training is guaranteed in the workplace, we can talk about an effective way to improve employment opportunities and thus a smooth transition from school to the labor market, which by facilitating the combination of work and education motivates to raise qualifications, especially since the majority of those already working prefer to be educated in the workplace than in the school environment. 


\section{SUMMARY}

In a situation of rapidly changing technologies and the need for specific skills entering the labour market, they need appropriate cognitive competences, enabling them to cope with various, specialist requirements of employers and other professional contexts, as well as with maintaining knowledge acquisition skills important in the knowledge society. It seems obvious that in the age of technological revolution the increase of the level of education is inevitable, which will certainly result in increased interest in employees in professions requiring the highest specialist competences, among which integrated competences will be sought in particular, for example: IT, financial, related to the use of alternative energy sources or medical.

In all initiatives to adapt the principles of vocational training to the challenges of today, it is worth remembering that the key element of effective vocational training are properly trained teachers. Unfortunately, in vocational education the staff is aging - in recent years Polish education suffers from a lack of teachers and vocational trainers, and many employees lack current experience in the work environment. It seems a good idea to employ vocational teachers at school and in the relevant industry sector in parallel to have current specialist knowledge in the field. At present, however, there are even no proposals for formal solutions in this field - persons supervising young employees in enterprises generally do not have any pedagogical training, while teachers do not even look for employment opportunities in enterprises.

Improving the effectiveness of practical classes organized as part of vocational education can be helped by helping social partners in the process of defining and shaping curricula (e.g. by co-shaping the substantive content of education by enterprises), improving the system of training vocational teachers, but also building a positive image of prospective professions in the context of globalization changes and developing career counseling. This creates a chance to build a strategy of conscious education, an active young employee with the ability to combine theoretical knowledge with practical skills to use it in future professional work.

\section{REFERENCES}

(access from 20/01/2019).

Act of 22 November 2018 amending the act - Educational law, act on the education system and some other acts (Journal of Laws of 2018, item 2245).

Banach C., 2001, Education. Value. Chance. Krakow, Publisher Scientific Pedagogical Academy. 
Bauman Z., 2006, Work, consumerism and new poor. Krakow, WAM Publishing House. Bylok F., 2012, Modern man between work and consumption, In: F. Bylok, U. Swadźba (eds.), Between work and consumption. What determines the place of man in modern society? Katowice, Publishing House of the University of Silesia.

Changing enterprises in politically changing Europe vol. 3, 2000, T. Wawak (ed.). Krakow, Economic Information Publishing House, Jagiellonian University.

Czerny M., Łuczak R., Makowski J., 2007, Globalistics: global processes and their local consequences. Warsaw, PWN.

Delors J., 1998, Education - there is a hidden treasure in it, Report for the UNESCO International Commission for Education for the 21st century. Warsaw, the Polish Educationalists Association.

Drucker P., 2001, The next society. "The Economist” 3 November, 79-91.

Dziewulak D., 2013, Vocational training in Poland and in selected European Union countries. BAS ISSN 1899 No. 6 (95) analyzes of April 22, 2013, downloaded from: https://edukator.ore.edu.pl (accessed on January 20, 2019)

Fazlagić J., 2015, The specificity of the Finnish education system against the background of Poland. "E-mentor", No. 2 (59), 4-15.

Gałkowska-Jakubik M., 2007, Have or be. Empirical verification of the concept of Erich Fromm. Lublin, Towarzystwo Naukowe KUL.

Globalization - an unbearable resemblance? The world and its institutions in the process of uniformization, 2008, B. Krauz-Mozer, P. Borowiec (eds.). Krakow, Jagiellonian University Press.

Hejnicka-Bezwińska T., 2008, General pedagogy. Warsaw, PWN.

Kabaj M., 2004, Strategies and programs for counteracting unemployment. Warsaw, Scholar Publishing House.

Kaczmarek T.T., 2011, Risk management. Interdisciplinary approach. Warsaw, Difin. Karczewska A., 2016, Globalization and consumerism as determinants of change and potential sources of threats in the sphere of work. "Scientific Papers of the Częstochowa University of Technology Management”, No. 24, vol. 2, 38-46.

Kuhn T., 2001, Structure of scientific revolutions. Warsaw, Aletheia.

Kukla D., 2006, Perspectives (not only professional youth in post-modernity. In: Youth on the labor market. From research to practice. S.M. Kwiatkowski, S. Sirojć (eds.). Warsaw, Difin, 65-69.

Kupisiewicz C., 2012, From the history of theory and practice of education. Krakow, Impuls Publishing House.

Kwatera A., 2010, Desiderates on the professional professionalization of teachers in the context of contemporary changes. In: Educational paradigms and teacher education. W. Kremie, T. Lewowicki, S. Sysojewa (eds.). Warsaw-Kraków, PWN. 
Kwiatkowski S.M., 2018, Competences of the future. In: S.M. Kwiatkowski (ed.), Competences of the future. Warsaw, Foundation for the Development of the Education System.

Lubik N., 2008, Globalization as a phenomenon and process. "Przegląd Politologiczny", No. 1, 89-94.

Maśloch P., 2005, Globalization and its impact on the development of modern civilization. "Entrepreneurship - Education", 1, 17-26.

Mazur M., 1970, Natural history of a Polish scientist. Warsaw, PIW.

Nowicka M., 2011, "Device”, "application", "system" - the dispositif category of Michel Foucault, its translations and their implications for post-oucauist analyzes of power. "Przegląd Socjologii Qualitative", vol. VII, No. 2, 94-110.

OECD, 2015, Building stronger pathways to work: the role of quality apprenticeships, base document prepared for the 2nd G20-OECD Conference on the promotion of high-quality professional practices. Retrieved from: https://www.oecd.org/.

Pacuk M., Anisiewicz R., Czochański J., Kopeć K., Połom M., Michalski T., Tarkowski M., 2016, Gdynia in the European Union. The living conditions. Gdańsk-Pelplin, University of Gdańsk, Bernardinum Publishing House.

Penc J., 2003, Strategic Management System. Warsaw, Placet.

Social Diagnosis 2011. In: J. Czapinski, T. Panek (eds.), Conditions and quality of life of Poles. Warsaw, Social Monitoring Council.

Sporek T., 2015, A new dimension in globalization and global problems. Scientific Works. Katowice, University of Economics in Katowice.

Szymański M.J., 2008, In search of the road. Chances and problems of education in Poland. Krakow, Jagiellonian University.

Tarkowski M., Palmowski T., Kopeć K., Wendt J., 2016, Gdynia in the European Union. Competitiveness of the economy. Gdańsk-Pelplin, University of Gdańsk, Bernardinum Publishing House.

Turbulence in World Politics: A Theory of Change and Continuity James N. Rosenau Princeton: Princeton University Press, 1990 [after]: J. Zdanowski, 2000, NonEuropean Cultures and Globalization. Warsaw, Elipsa Publishing House.

Uberman M., 2008, Man and art. In the context of livelong concepts. In: V. Uzelac, L. Vujicic (eds.), Cjelozivotno ucenije za odvzivi razvoj. Rijeka, Sveucilisna Knjiznica Rijejka. 


\section{GLOBALIZACJA JAKO WYZWANIE DLA EDUKACJI ZAWODOWEJ}

Streszczenie: Niniejszy artykuł dotyczy edukacji zawodowej jako elementu globalizacji we współczesnym świecie. Celem artykułu jest ustalenie podstawowej problematyki w zakresie miejsca edukacji zawodowej w czasach globalizacji. W artykule skoncentrowano się na takich kwestiach, jak specyfika edukacji zawodowej w Polsce i na świecie, znaczenie edukacji zawodowej dla współczesnego świata, pojęcie i cechy globalizacji, jak również determinanty/ uwarunkowania globalizacji we współczesnym świecie i edukacja zawodowa jako efekt globalizującego się świata. Człowiek, z obywatela danego państwa, stał się obywatelem świata. Fakt ten niesie ze sobą zarówno dużo zalet, jak i zagrożeń, w tym w sferze edukacji zawodowej, dla której wszechobecne przemiany przyniosły wiele nowych wyzwań. Dotyczy to zwłaszcza przystosowania programów nauczania do potrzeb społeczeństw funkcjonujących w nowych warunkach gospodarczych, społecznych i kulturowych, w tym podjęcia działań zmniejszających dysproporcję między opanowywaną przez uczniów wiedzą a umiejętnościami czy rozszerzenia kształcenia specjalistycznego. Szkolnictwo zawodowe musi zmierzyć się z koniecznością zmiany priorytetów, aby zgodnie z trendami globalizacyjnymi kształcić mobilnych pracowników gospodarki rynkowej, aktywnych i zdolnych do ciągłego samokształcenia.

Słowa kluczowe: edukacja zawodowa, globalizacja, kompetencje przyszłości, kształcenie specjalistyczne 